\title{
Heterogeneity of DNA distribution pattern in renal tumours
}

\author{
Hans Nenning ${ }^{1, *}$, Jörg Raßler ${ }^{2}$ and Do Hoan Minh ${ }^{2}$ \\ ${ }^{1}$ Institute of Pathology, University of Leipzig, Germany \\ ${ }^{2}$ Department of Urology, University of Leipzig, Germany
}

Received 17 September 1996

Revised 12 February 1997

Accepted 19 March 1997

\begin{abstract}
The presence of intratumoural heterogeneity in DNA distribution patterns has been accepted. However, most previous studies have not taken this fact into consideration. The value of DNA cytometry depends on its reproducibility. This could be influenced by heterogeneity failure. The aim of the present study is to evaluate intratumoural heterogeneity in renal cell cancer.

A sample of 22 tumours of the kidney was investigated by means of static DNA cytometry: 21 tumours were carcinomas, one was an angiomyolipoma. Probes from seven different locations of each tumour were Feulgen-stained and measured. The variability of DNA features was determined and correlated with histological grade and type and with tumour size.

There was considerable intratumoural heterogeneity with respect to DNA distribution pattern in $45 \%$ of the tumours. Additional non-diploid tumour-stemlines and deviation of computed DNA features could be found in several cases by measuring more than one slide per tumour. A correlation between tumour heterogeneity, grading or typing, and tumour size could not be found.

Because these DNA parameters could serve as the foundation of a risk-adapted treatment, tumour heterogeneity could have clinical consequences. Based on the results of this study we suggest measuring at least three slides per tumour to avoid misinterpretation of DNA measurements in renal cell cancer.
\end{abstract}

Keywords: DNA cytometry, renal cell cancer, intratumoural heterogeneity, prognosis

\section{Introduction}

Measurements of nuclear DNA content have been used as a prognostic indicator in patients with malignant tumours. Their value could be shown in malignant tumours of the kidneys in several studies [2,3,10,15-19,27,28]. Others studies failed to confirm these findings [14,20,30,32,34].

Although the presence of intratumoural heterogeneity in DNA distribution pattern has been accepted, most previous studies have not taken this fact into consideration. The capability of DNA cytometry depends on its reproducibility $[7,17,22,29]$. The aim of the study was to evaluate the degree of the intratumoural heterogeneity of DNA parameters by means of static image cytometry in tumours of the kidney. The degree of differences should be correlated with the grade of differentiation and size of the tumours. The results of the study should suggest an appropriate number of probes for accurate DNA cytometry in renal tumours.

\footnotetext{
${ }^{*}$ Corresponding author: Dr. Hans Nenning, Institute of Pathology, University of Leipzig, 04103 Leipzig, Germany. Tel.: +493419715027; Fax: +493419715009.
}

0921-8912/97/\$8.00 @ 1997 - IOS Press. All rights reserved 


\section{Material and methods}

\subsection{Patients and tumours}

Specimens from 22 patients suffering from tumours of the kidney were investigated. 10 of the patients were women, 12 were men. The mean age was 65.1 years (from 40 up to 77 years). From each tumour at least 5 samples were investigated histologically. Histological grading and typing was performed according to Thoenes [33].

\subsection{Slide preparation}

Immediately after tumour resection, a section of $1 \mathrm{~cm}^{3}$ in size was made from 7 non-necrotic tumour areas (see Fig. 1). From each tissue piece three to five smear preparations of the section were fixed on an uncoated glass slide. The glass slides were air-dried and kept away from light until staining. One slide of each location was stained. Prior to the actual staining, all preparations were fixed for 10 min in 4\% neutral formalin [13]. To determine the quantity of DNA content, Feulgen-reaction was performed [23]: Sour hydrolysis in $5 \mathrm{~N} \mathrm{HCl}$ for $30 \mathrm{~min}$ at $25^{\circ} \mathrm{C}$ and subsequent staining for $60 \mathrm{~min}$ in Schiff's reagent followed by routine dehydration with Canada balsam serving as an adhesive.

\subsection{Image analysis}

The measurement of stained preparations was performed within 14 days using system Cue2 (Olympus, Japan). For the measurements the system was connected to a microscope BH-2 (Olympus) with objective $40 \times$, interference filter $560 \mathrm{~nm}$ and black and white TV camera (XC-57CE, Sony, Japan) with a pixel resolution $512 \times 512$. All slides of one tumour were measured on the same day. At

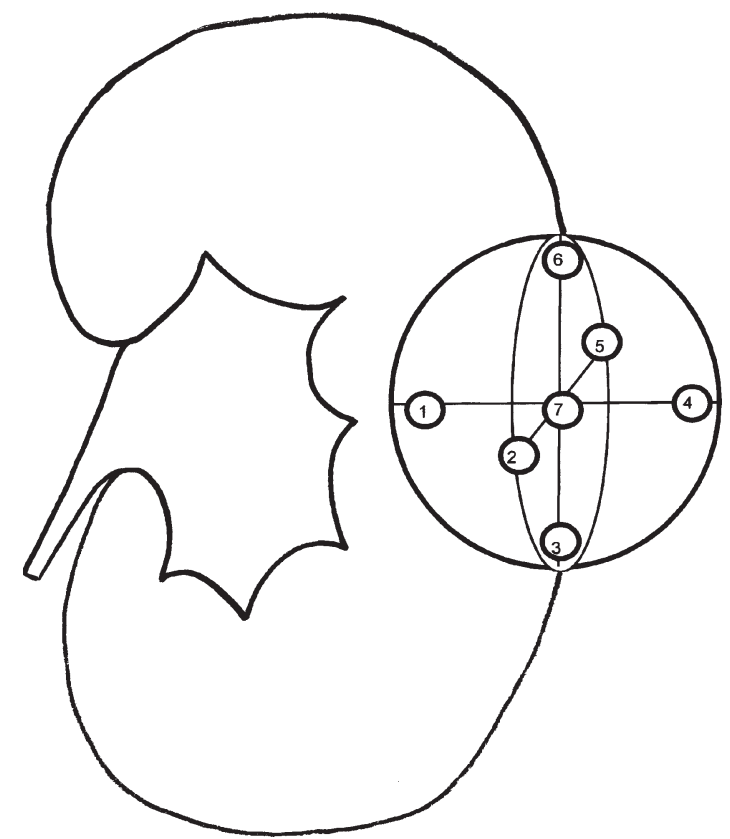

Fig. 1. Tissue acquisition from seven different locations in renal tumours. 
least 200 tumour cells as well as 20-30 granulocytes per preparation as internal reference cells were measured interactively. Glare corretion was not available for the used system. That is why a CV of lower than $7 \%$ was accepted althought it was recommended that the $\mathrm{CV}$ of reference cells should not exceed $5 \%$ [5].

\subsection{DNA parameters}

The following DNA parameters were calculated using ploidy software (Ver. 6.2, Galai, Israel): stemline ploidy (ratio of DNA content between tumour-stemline and diploid reference cells; DNA index), 5c-exceeding rate (rate of cells with DNA content higher than 5c), 2c-deviation index and DNA-grade of malignancy [6]. Regarding the DNA index of the highest tumour-stemline, the ploidy status was determined: The statement of DNA aneuploidy was based on the conventional DNA stemline interpretation which assumes aneuploidy if the stemline ploidy differs more than $\pm 10 \%$ from the median of the reference cells. Tumour cell stemlines within $\pm 10 \%$ of the double median of the reference cells were regarded as peritetraploid [5]. Only the highest peak was considered for determining ploidy status in tumours with more than one peak (e.g., peridiploid and peritetraploid).

In addition, the DNA distribution histograms were classified according to a modified Auer classification [1] as described below. All classifications were performed by one expert investigator. The

\section{Type I}

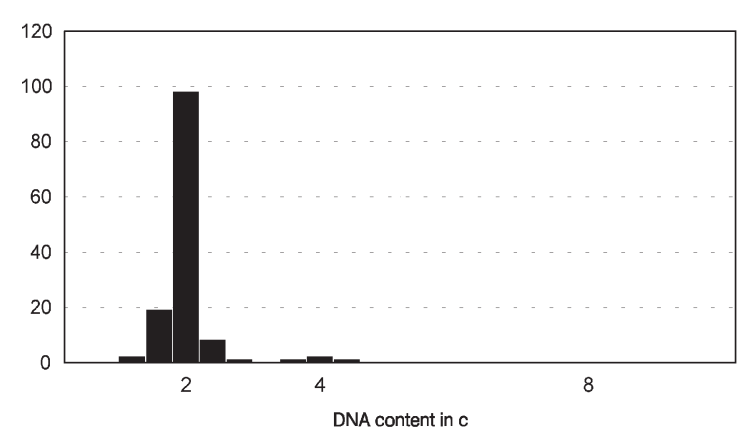

\section{Type III}

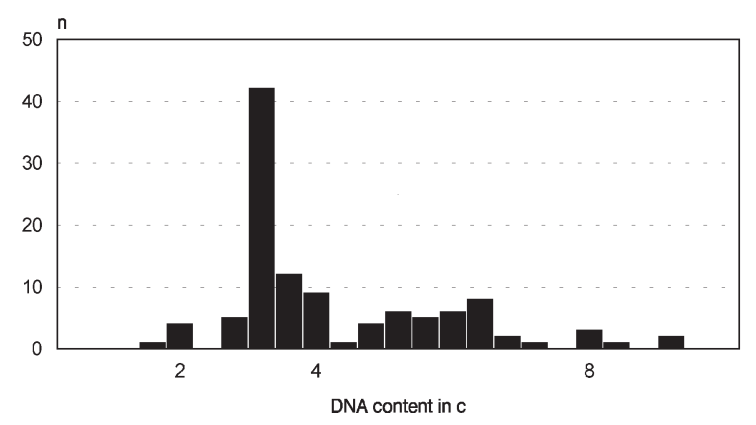

Type II

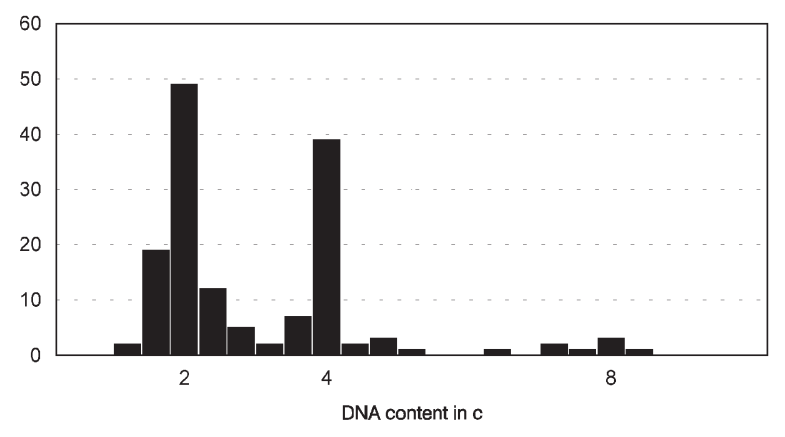

\section{Type IV}

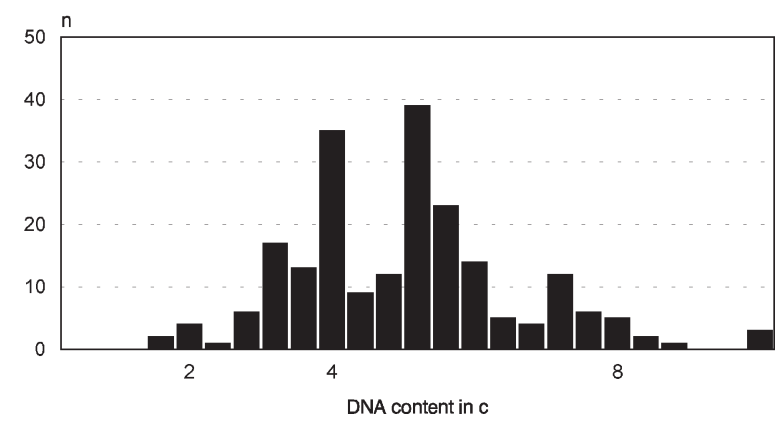

Fig. 2. DNA distribution pattern regarding the histogram classification. 
classification consists of four categories. Type I histogram represents one single peak in the peridiploid region with some cells near 4c. Type II histogram is characterised by either a distinct peak in the peritetraploid region or two peaks in peridiploid and peritetraploid regions, and some cells near 8c. Type III shows an aneuploid, non peritetraploid peak, with or without an additional peridiploid peak. Type IV histogram shows a wide range of DNA values with several peaks and cells exceeding the $4 \mathrm{c}$ region (see Fig. 2).

\subsection{Statistical evaluation}

For each tumour, the mean value, minimum, maximum, standard deviation and variance of the computed DNA parameters were determined. The results of DNA cytometry were compared with tumour size and histological grade of differentiation (Mann-Whitney's u-test). Evaluation was performed using statistic package SPSS for Windows. A difference was considered to be significant if the $p$-value was lower than 0.05 .

\section{Results}

Of the tumours 21 were carcinomas, 18 of clear cell type, two were tubulo-papillary carcinomas and one was a Duct-Bellini carcinoma [33]. One tumour was classified as angiomyolipoma as result of the histological investigation. The benign nature of the tumour was unknown at the time of operation; it was considered as a carcinoma and the involved kidney was resected. It is known, that grading is not allowed for benign tumours. But we have included this tumour in our study, because heterogeneity has been seen in benign lesions, as well.

The mean tumour size was $247.2 \mathrm{~cm}^{3}$ (from 1.7 up to $1287 \mathrm{~cm}^{3}$ ).

Five of the carcinomas were classified as G1-tumours, 12 as G2-tumours and 4 as G3-carcinomas.

The distribution of the histogram types is shown in Table 1 . In $12(54 \%)$ cases only one type was determined, in ten cases (46\%) more than one histogram type was found. Ploidy status of the tumour samples in shown in Table 2. Of the 22 tumours 14 (64\%) were homogeneously diploid, and in seven cases $(32 \%)$ diploid and non-diploid tumour stemlines were detected, one tumour was in all samples non-diploid with respect to its highest peak.

The distribution of the DNA parameters 5c-exceeding-rate, DNA grade of malignancy and 2cdeviation index is given in Tables 3-5.

\section{Discussion}

Accuracy and reproducibility of DNA content measurements are essential when using this method for characterisation of tumours [22]. In addition to measuring and preparation, interest has been focused on the heterogeneity of tumours in the past years. It is well recognised that tumours often consist of subpopulations with different clones, including different DNA ploidy. Several studies revealed that the distribution of DNA parameters in one tumour depends on its size and grade of differentiation. These authors suggested that the measurements be made on more than one slide to characterise the tumour more precisely $[7,8,11,12,17,25,29,31]$.

Tumours of the kidney are often large. Histological examination shows differences in structure and differentiation. Thus it seems possible that there are differences in DNA distribution pattern as well. 
Table 1

Distribution of the different histogram types in the investigated tumours

\begin{tabular}{ccccc}
\hline Case & Type I & Type II & Type III & Type IV \\
\hline 1 & 1 & 6 & & \\
2 & 7 & & & \\
3 & 7 & 4 & & \\
4 & 2 & & & \\
5 & 7 & & & \\
6 & 7 & & & \\
7 & 7 & 3 & & \\
8 & 7 & 1 & & \\
9 & 7 & & & \\
10 & 3 & & & \\
11 & 6 & 3 & & \\
12 & 7 & & & \\
13 & 7 & 6 & & \\
14 & 4 & & & \\
15 & 7 & & & \\
16 & 1 & & & \\
17 & 3 & & & \\
18 & 3 & & & \\
19 & 6 & & & \\
20 & 7 & & & \\
21 & & & & \\
22 & & & & \\
\hline
\end{tabular}

Table 2

Ploidy status of the different tumour locations

\begin{tabular}{cccccccc}
\hline Case & Loc. 1 & Loc. 2 & Loc. 3 & Loc. 4 & Loc. 5 & Loc. 6 & Loc. 7 \\
\hline 1 & d & d & d & d & d & d & d \\
2 & d & d & d & d & d & d & d \\
3 & d & d & d & d & d & d & d \\
4 & d & a & d & d & d & t & d \\
5 & d & d & d & d & d & d & d \\
6 & d & d & d & d & d & d & d \\
7 & d & d & d & d & d & d & d \\
8 & d & d & d & d & d & d & d \\
9 & d & d & d & d & d & d & d \\
10 & d & t & d & d & d & d & d \\
11 & d & d & d & d & d & t & d \\
12 & d & d & d & d & d & d & d \\
13 & d & d & d & d & d & d & d \\
14 & a & a & t & a & a & a & a \\
15 & d & d & d & d & d & d & d \\
16 & d & d & d & d & d & d & d \\
17 & d & t & d & d & t & d & d \\
18 & d & d & d & t & d & t & d \\
19 & d & d & d & t & d & d & d \\
20 & d & d & d & d & d & a & t \\
21 & d & d & d & d & d & d & d \\
22 & d & d & d & d & d & d & d \\
\hline
\end{tabular}

$\mathrm{d}=$ DNA-diploid, $\mathrm{t}=$ DNA-tetraploid, $\mathrm{a}=$ DNA-aneuploid. 
Table 3

Distribution of the 5c-exceeding-rates $(5 \mathrm{cER}$; in \%) in the investigated tumours

\begin{tabular}{cllcc}
\hline Case & 5 cER & $\min$ & $\max$ & $\mathrm{dev}$ \\
\hline 1 & 4.62 & 0.51 & 12.5 & 3.8 \\
2 & 0.2 & 0 & 0.97 & 0.37 \\
3 & 0.133 & 0 & 0.48 & 0.23 \\
4 & 7.7 & 0 & 35.9 & 12.9 \\
5 & 0 & 0 & 0 & \\
6 & 0.106 & 0 & 0.4 & 0.18 \\
7 & 0.204 & 0 & 0.98 & 0.38 \\
8 & 0.86 & 0 & 1.82 & 0.61 \\
9 & 0.32 & 0 & 0.89 & 0.34 \\
10 & 2.18 & 0 & 7.11 & 2.62 \\
11 & 3.92 & 0 & 15.34 & 5.76 \\
12 & 0.15 & 0 & 0.56 & 0.26 \\
13 & 0.24 & 0 & 0.65 & 0.3 \\
14 & 2.62 & 0.51 & 5.45 & 1.7 \\
15 & 2.98 & 0.46 & 6.25 & 2.42 \\
16 & 1.43 & 0 & 3.11 & 1.23 \\
17 & 5.6 & 0.52 & 11.4 & 4.3 \\
18 & 1.73 & 0.52 & 3.92 & 1.13 \\
19 & 4.17 & 0 & 14.7 & 4.99 \\
20 & 3.75 & 0.75 & 10.78 & 3.59 \\
21 & 1.8 & 0 & 10.82 & 3.99 \\
22 & 0.2 & 0 & 0.54 & 0.25 \\
\hline
\end{tabular}

min: minimal value; max: maximal value; dev: standard deviation.

Table 4

Distribution of the DNA grades of malignancy (MG) in the investigated tumours

\begin{tabular}{cllll}
\hline Case & MG & min & $\max$ & dev \\
\hline 1 & 0.844 & 0.42 & 1.24 & 0.26 \\
2 & 0.18 & 0.13 & 0.22 & 0.04 \\
3 & 0.114 & 0.05 & 0.17 & 0.04 \\
4 & 0.92 & 0.19 & 2.13 & 0.68 \\
5 & 0.114 & 0.05 & 0.16 & 0.04 \\
6 & 0.236 & 0.13 & 0.38 & 0.07 \\
7 & 0.163 & 0.12 & 0.19 & 0.03 \\
8 & 0.33 & 0.18 & 0.46 & 0.09 \\
9 & 0.23 & 0.18 & 0.32 & 0.06 \\
10 & 0.54 & 0.22 & 1.32 & 0.43 \\
11 & 0.48 & 0.07 & 1.48 & 0.52 \\
12 & 0.106 & 0.08 & 0.14 & 0.024 \\
13 & 0.116 & 0.04 & 0.21 & 0.06 \\
14 & 0.82 & 0.64 & 1.28 & 0.22 \\
15 & 0.61 & 0.4 & 1.04 & 0.24 \\
16 & 0.32 & 0.19 & 0.43 & 0.1 \\
17 & 0.87 & 0.21 & 1.34 & 0.38 \\
18 & 0.83 & 0.39 & 1.12 & 0.27 \\
19 & 0.783 & 0.1 & 1.4 & 0.44 \\
20 & 0.69 & 0.21 & 1.18 & 0.39 \\
21 & 0.25 & 0.03 & 1.07 & 0.38 \\
22 & 0.24 & 0.05 & 1.12 & 0.39 \\
\hline
\end{tabular}

min: minimal value; max: maximal value; dev: standard deviation. 
Table 5

Distribution of the 2c-deviation-indices $(2 \mathrm{cDI})$ in the investigated tumours

\begin{tabular}{cllcl}
\hline Case & 2cDI & $\min$ & $\max$ & dev \\
\hline 1 & 2.18 & 0.72 & 4.08 & 1.09 \\
2 & 0.271 & 0.18 & 0.34 & 0.07 \\
3 & 0.164 & 0.07 & 0.26 & 0.065 \\
4 & 3.87 & 0.28 & 15.3 & 5.2 \\
5 & 0.166 & 0.07 & 0.24 & 0.06 \\
6 & 0.37 & 0.19 & 0.66 & 0.14 \\
7 & 0.24 & 0.16 & 0.29 & 0.05 \\
8 & 0.55 & 0.26 & 0.82 & 0.18 \\
9 & 0.36 & 0.27 & 0.53 & 0.115 \\
10 & 1.36 & 0.34 & 4.61 & 1.66 \\
11 & 1.39 & 0.1 & 5.98 & 2.14 \\
12 & 0.15 & 0.1 & 0.21 & 0.04 \\
13 & 0.17 & 0.05 & 0.32 & 0.096 \\
14 & 2.04 & 1.32 & 4.35 & 1.05 \\
15 & 1.33 & 0.68 & 2.9 & 0.84 \\
16 & 0.53 & 0.28 & 0.76 & 0.19 \\
17 & 2.44 & 0.31 & 4.79 & 1.52 \\
18 & 2.13 & 0.68 & 3.33 & 1.03 \\
19 & 2.19 & 0.14 & 5.26 & 1.77 \\
20 & 1.76 & 0.32 & 3.7 & 1.33 \\
21 & 0.58 & 0.04 & 3.04 & 1.1 \\
22 & 0.13 & 0.07 & 0.21 & 0.05 \\
\hline
\end{tabular}

min: minimal value; max: maximal value; dev: standard deviation.

We assume that a representative number of probes have been taken to detect these differences by using seven different samples of each tumour.

Considering the stemline ploidy and the histogram classification, four types of tumours could be distinguished:

1. DNA-peridiploid tumours without an additional stemline (11 tumours);

2. DNA-peridiploid tumours with an additional peritetraploid stemline (six tumours);

3. DNA-peridiploid tumours with an additional non-tetraploid aneuploid stemline (two tumours); and

4. DNA-non-tetraploid aneuploid tumours (one tumour).

The number of non-diploid stemlines in tumours of group 2 and 3 ranges from one to six. In most cases the non-diploid tumour cell population could be detected in three or more tumour specimens. Only the highest peak of the DNA histogram was considered for determining the DNA index and the ploidy status of the tumour specimen. Tumours with a DNA-diploid stemline could be classified as histogram type I, II or III depending on an additional lower peak (see Tables 1 and 2). Considering cytogenetic investigations in renal cell carcinomas, the occurrence of peritetraploid stemlines is correlated with tumour progression (secondary chromosomal aberrations, [9]). This feature could be regarded as an unfavourable prognostic factor [5]. The absence of the non-diploid tumour part caused by unrepresentative material could result in misinterpretation of DNA measurement.

The degree of divergence of 5c-exceeding-rate, DNA-grade of malignancy and 2c-deviation-index of each tumour correlates with the range of the DNA histogram pattern. A reasonable conformity in histogram type between the different tumour parts is accompanied by a low divergence in computed DNA parameters. Occurrence of aneuploid stemlines results in an increase of the 2c-deviation-index and, in most cases, of 5c-exceeding-rate. 
To distinguish between good and poor prognosis of patients with malignant tumours based on DNA parameters, it is necessary to set a cut-off point for the computed DNA features. Tumours with parameters greater than this value will be regarded as high-risk cases, and an additional treatment is recommended. We found such limits for renal cell carcinoma with respect to the occurrence of distant metastases in earlier studies [24,26]. Tumours with grade of malignancy greater than 0.5 or with a non-diploid stemline had a significantly higher rate of distant metastases in clinical follow up. A special treatment for these patients was suggested. A detected value lower than this level caused by heterogeneity failure could result in undertreatment of the patients. A difference could not be found between DNA aneuploid and DNA tetraploid tumours.

A considerable intratumoural heterogeneity of DNA parameters could be detected in $45 \%$ in the tumours investigated in the present study. These results correspond to the results of other authors who have used flow cytometry in renal cell cancers [21]. There was no correlation between tumour size and heterogeneity. The smallest tumour $\left(1.7 \mathrm{~cm}^{3}\right)$ had an additional peritetraploid peak in one slide; the largest tumour $\left(1287 \mathrm{~cm}^{3}\right)$ was homogenous with respect to its DNA pattern. The one benign tumour investigated in this study showed no sign of malignancy in any location. It had a peridiploid stemline and low levels of computed DNA parameters.

A statistic correlation between grade of histological differentiation, tumour type and intratumoural heterogeneity could not be found. Heterogeneity occurred in G1- and G2-, as well as in G3-tumours. It seems to be possible, that the results of the authors, which did not confirm a correlation between DNA parameters and prognosis in renal cell cancer, could be influenced by heterogeneity failure [4].

The follow-up time of our tumour patients is too brief to analyse the clinical impact of tumour heterogeneity. In the study of Ljungberg et al. [21] heterogeneity itself, evaluated by flow cytometry, had no prognostic significance in renal cell carcinoma. But it is obvious that multiple sampling is recommended in order to properly evaluate the malignant potential of renal carcinoma. Measuring of a mixture of samples was suggested for flow cytometric investigations [4]. Recommendations for image cytometry are not available for renal cell carcinoma to our knowledge. We suggest, based on the results of this study, that three samples of each carcinoma of the kidney be made to get representative results of DNA measurements, independently of tumour size and grading to obtain a high probability of the DNA features of the tumour part with the highest malignant potential.

\section{References}

[1] G. Auer, E. Eriksson, E. Azavedo, T. Caspersson and A. Wallgren, Prognostic significance of nuclear DNA content in mammary adenocarcinomas in humans, Cancer Res. 44 (1984), 394-396.

[2] H. Baisch, U. Otto, K. König, G. Klöppel, M. Köllermann and W.A. Linden, DNA content of human kidney carcinoma cells in relation to histological grading, Br. J. Cancer 45 (1982), 878-886.

[3] H. Baisch, U. Otto and G. Klöppel, Malignancy index based on flow cytometry and histology for renal cell carcinomas and its correlation to prognosis, Cytometry 7 (1986), 200-205.

[4] S.C. Barranco, R.R. Perry, M.E. Durm, A.L. Werner, S.H. Gregorcyk, W.E. Bolton, P. Kolm and M. Townsend, Intratumoral variability in prognostic indicators may the cause of conflicting estimates of patient survival and response to therapy, Cancer Res. 54 (1994), 5351-5356.

[5] A. Böcking, DNA measurements. When and why? Compendium on quality assurance, proficiency testing and workload limitations in clinical cytology, 1995, pp. 170-188.

[6] A. Böcking and W. Auffermann, Algorithm for DNA cytophotometric diagnosis and grading of malignancy (letter), Anal. Quant. Cytol. Histol. 6 (1986), 363.

[7] A. Böcking, R. Chatelain, M. Homge, R. Daniel, A. Gillisen and D. Wohltmann, Representativity and reproducibility of DNA malignancy grading in different carcinomas, Anal. Quant. Cytol. Histol. 11 (1989), 81-86.

[8] E. Fujimaki, K. Sasaki, O. Nakano, S. Chiba, H. Tazawa, H. Yamashiki, S. Orii and T. Sugai, DNA ploidy heterogeneity in early and advanced gastric cancers, Cytometry 26 (1996), 131-136. 
[9] L. Füzesi, Zytogenetik und DNA-Zytometrie der Tumorprogression bei Nierenzellkarzinomen, Med. Habil. Schr., RWTH Aachen, 1993.

[10] D.J. Grignon, A. El-Naggar, L.K. Green, A.G. Ayala, J.Y. Ro, D.A. Swanson, P. Troncoso, D. McLemore, G.G. Giacco and V.F. Guinee, DNA flow cytometry as a predictor of outcome of stage renal cell carcinoma, Cancer 63 (1989), $1161-1189$.

[11] W. Hiddemann, D.B. von Bassewitz, H.J. Kleinemeier, E. Schulter-Brochterbeck, J. Hauss, B. Lingemann, T. Büchner and E. Grundmann, DNA stemline heterogeneity in colorectal cancer, Cancer 58 (1986), 258-263.

[12] U. Köhler, G. Naumann, H. Nenning, G. Taubert and K. Bilek, Untersuchungen zur Variabilität von quantitativen DNA-Parametern in Endometriumkarzinomen, Zentralbl. Gynäkol. 116 (1994), 609-613.

[13] H. Krug, Histo- und Zytophotometrie, Fischer, Jena, 1980.

[14] D. Lanigan, P.A. McLean, D.M. Murphy, M.G. Donovan, B. Curran and M. Leader, Ploidy and prognosis in renal carcinoma, Br. J. Urol. 71 (1993), 21-24.

[15] B. Ljungberg, G. Forsslund, R. Stenling and A. Zetterberg, Prognostic significance of the DNA content in renal cell carcinoma, J. Urol. 135 (1986), 422-426.

[16] B. Ljungberg, R. Stenling and G. Roos, Prognostic value of desoxyribonucleic acid content in metastatic renal cell carcinoma, J. Urol. 136 (1986), 801-804.

[17] B. Ljungberg, R. Stenling and G. Roos, DNA content in renal cell carcinoma with reference to tumour heterogeneity, Cancer 56 (1985), 503-508.

[18] B. Ljungberg, R. Stenling and G. Roos, DNA content and prognosis in renal cell carcinoma, Cancer 57 (1986), 2346-2350.

[19] B. Ljungberg and G. Roos, Value of DNA analysis for treatment of renal cell carcinoma, Eur. Urol. 18(2) (1990), 31-34.

[20] G. Ljungberg, I. Nordenson and G. Roos, Cytogenetic and flowcytometric DNA analysis in renal cell carcinoma, Eur. Urol. 19 (1991), 59-62.

[21] G. Ljungberg, C. Mehle, R. Stenling and G. Roos, Heterogeneity in renal cell carcinoma and its impact on prognosis a flow cytometric study, Br. J. Cancer 74 (1996), 123-127.

[22] A. Marchewski, T. Tolmachoff and S. Lee, Quality assurance issue in DNA image cytometry, Cytometry 26 (1996), 101-107.

[23] D. Müller, Erfahrungen mit der Feulgenfärbung für quantitative cytochemische DNS-Untersuchungen, Histochemie 7 (1966), 96-102.

[24] H. Nenning, J. Raßler and M. Do, DNA cytometry in renal cell carcinoma, Gen. Diagn. Pathol. 141 (1995/96), 243-247.

[25] H. Nenning, G. Taubert, U. Köhler and G. Naumann, Variabilität von DNA-Parametern innerhalb maligner Tumoren des Endometriums, Verh. Dtsch. Ges. Path. 79 (1995), 586.

[26] H. Nenning, G. Taubert, J. Raßler, J. Asmussen and M. Do, Prognostic value of DNA parameters in renal cell cancer, Pathol. Res. Pract. 192(4) (1996), 358.

[27] G. Raviv, I. Leibovich, Y. Mor, D. Nass, O. Medalia, B. Goldwasser and O. Nativ, Localized renal cell carcinoma treated by radical nephrectomy. Influence of pathologic data and the importance of DNA ploidy pattern on disease outcome, Cancer 72 (1993), 2207-2212.

[28] G. Roos and B. Ljungberg, DNA content in renal cell carcinoma and its clinical significance, Eur. Urol. 18(2) (1990), 29-30.

[29] O. Sasaki, K. Soejima and Y. Haraguchi, Intra-tumour DNA ploidy distribution pattern and its relation to histologic type in gastric carcinoma, Path. Res. Pract. 188 (1992), 545-549.

[30] H.W. Schwabe, H.D. Adolphs and J. Vogel, Flow-cytophotometric studies in renal cell carcinoma, Urol. Res. 11 (1983), 121-124.

[31] S. Stipa, D.T. Danesi, C. Modini, F. Cicconetti, F. Mauro, A. Schillaci, A. Mecocci, V. Nicolanti, F. Stipa, M. Mancini, C. Bangrazi and C. Botti, The importance of heterogeneity and of multiple site sampling in the prospective determination of desoxyribonucleic acid flow cytometry, Gynecol. Obstet. 176 (1993), 427-434.

[32] A. Tannapfel, H.A. Hahn, A. Katalinic, R.F. Fietkau, R. Kühn and C.W. Wittekind, Prognostic value of ploidy and proliferation markers in renal cell carcinoma, Cancer 77(1) (1996), 164-171.

[33] W. Thoenes, S. Störkel and H.J. Rumpelt, Histopathology and classification of renal cell tumours (Adenomas, oncocytomas and carcinomas). The basic cytological and histopathological elements and their use for diagnostics, Path. Res. Pract. 181 (1986), 125-143.

[34] D.S. Yu, C.M. Hsu, W.H. Lee, S.Y. Chang and C.P. Ma, Flow cytometric DNA and cytomorphometric analysis in renal cell carcinoma: Its correlation with histopathology and prognosis, J. Surg. Res. 55 (1993), 480-485. 


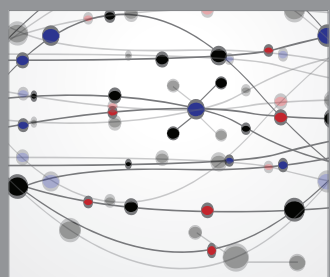

The Scientific World Journal
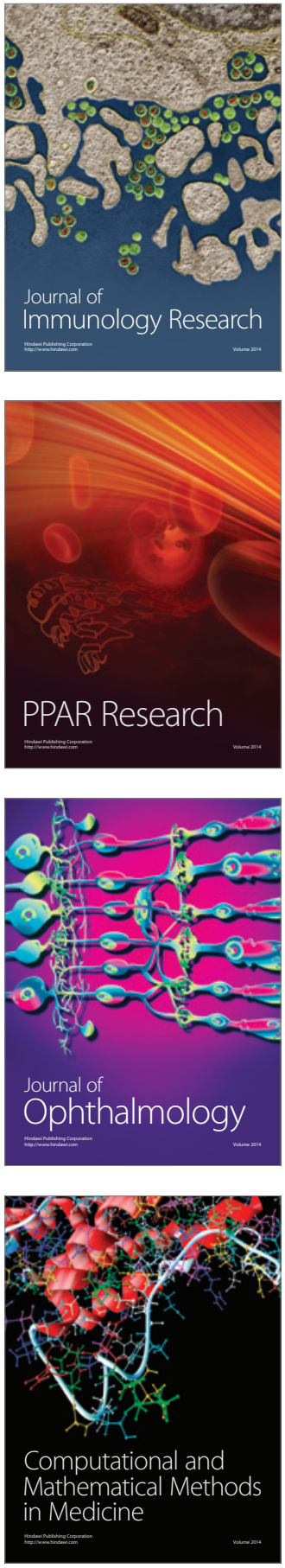

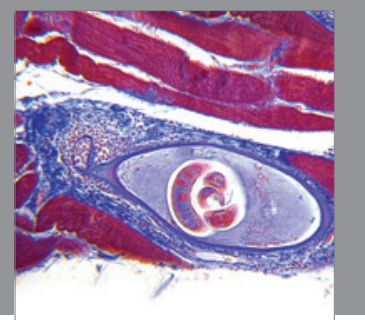

Gastroenterology

Research and Practice
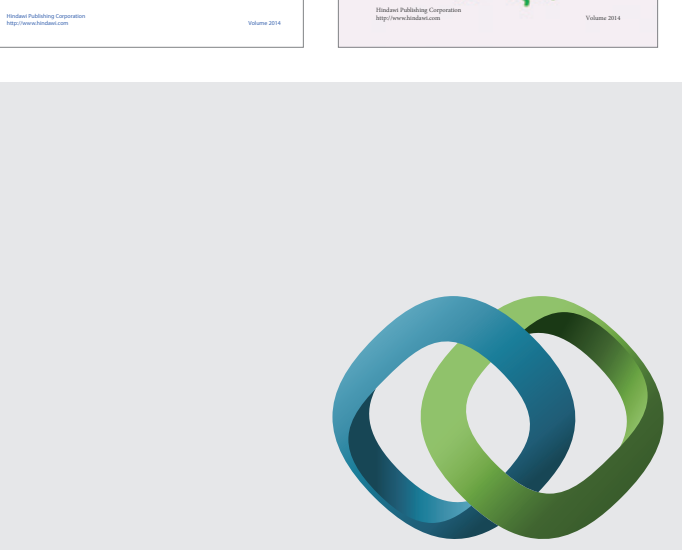

\section{Hindawi}

Submit your manuscripts at

http://www.hindawi.com
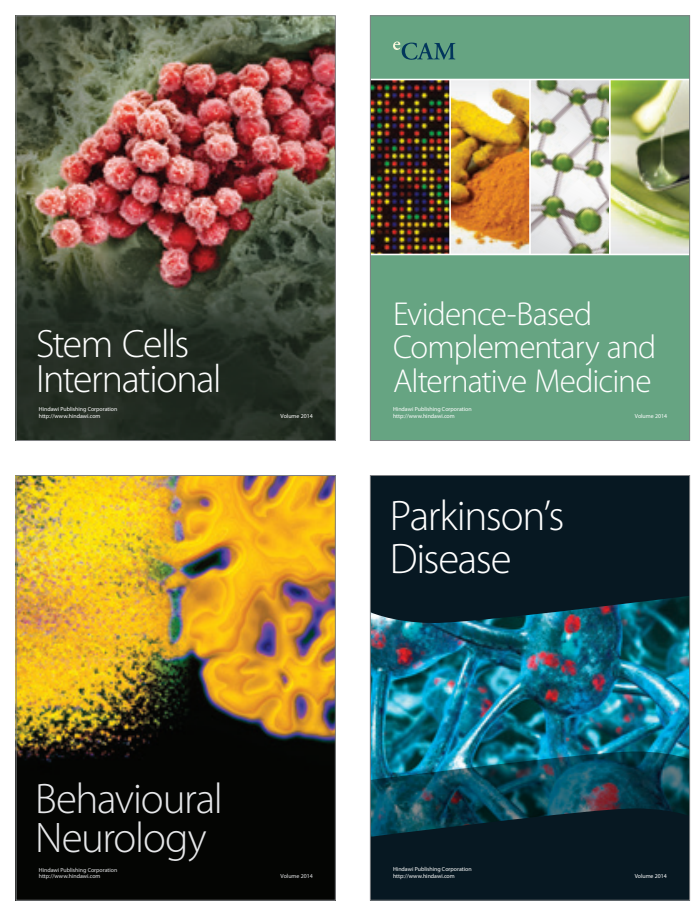

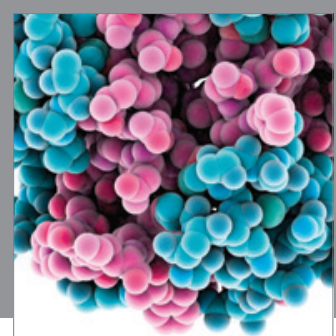

Journal of
Diabetes Research

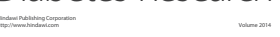

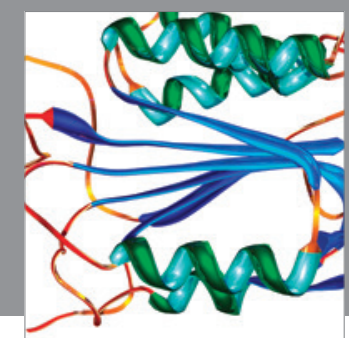

Disease Markers
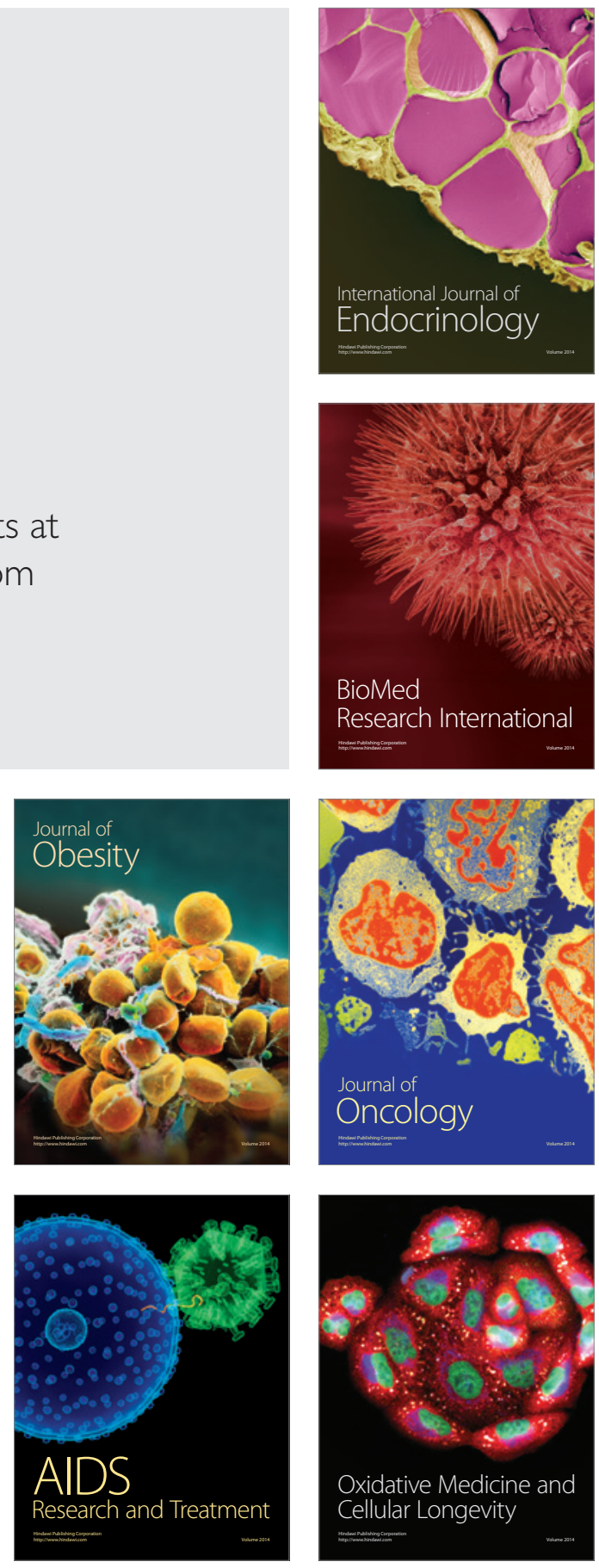